\title{
Methodology of multiaxial machines formats volumetric accuracy comparative evaluation
}

\author{
Svetlana Lukina ${ }^{1, *}$, and Igor Manaenkov ${ }^{1}$ \\ ${ }^{1}$ Moscow polytechnic university, 38 B.Semyonovskaya st., Moscow 107023, Russian Federation
}

\begin{abstract}
The main characteristic of machine tool system, providing the most efficient multi-axis processing, is machine volumetric accuracy, which may be demonstrated in the machine working space. The development of methods and means of controlling volumetric accuracy is a very important engineering and process task. Solving this issue may ensure competitive ability of the domestic fixtures and tools for multi-axis form making during the treatment with the help of power tools. Early project stage is the most important one, as the success of the machine project itself highly depends on the right choice of arrangement. In this research, we presented design scheme of machine-tool unit, stated its initial and boundary conditions, and also there was developed a model of comparative assessment of elastic displacement in the working space. Volumetric accuracy is formed by means of inaccuracy space field of the processing system, which occur in the formation zone under the influence of agitation, which may be determined by simulation and analytical modeling of machine tool system. Within the framework of this research, there was developed the method of comparative assessment of volumetric accuracy of multi-axis machine compositions with not less than 5 interpolate axis.
\end{abstract}

\section{Introduction}

The modern stage of technological system development for high-technology treatment is characterized by increase of competitiveness in the sector of produced manufacturing equipment. It is shown in raised demands for quality, reliability and multitask functionality of technological machines, which are caused by appearance and study of new high-precision and high-production technologies [1].

Development of methods and means for formation precision control is a very important project and technological task for multi-axis treatment of details with curved surfaces $[7,8]$. Solving this issue may ensure competitive ability of the domestic machine-tools and increase effectiveness of multi-axis form making.

Low level volumetric accuracy of machine tool systems and the absence of multifaceted approach for ensuring the multi-axis form making during the stage of preparing and introduction of new constructive decisions for multi-axis machine tools are the reasons for the lack of effectiveness in multi-axis formation, which is certainly an engineering and manufacturing problem. [2].

The main characteristic of the machine tool system, which ensures most effective multi-axis treatment is the machine volumetric accuracy which is displayed in its working space. $[6,10,14]$

The aim of this research is the creation of the method of comparative assessment of multi-axis machine compositions volumetric accuracy (with not less than 5 interpolate axis) in order to find the best constructive decisions "for technological tasks" considering certain manufacturing conditions.

The development of methods and means of controlling volumetric accuracy is a very important engineering and process task.

\section{Principal provisions of comparative assessment methods for volumetric accuracy of multi-axis machine tools}

Volumetric accuracy of metal-working machine means integral characteristics showing its ability to provide certain form-making accuracy level as well as the technological system error law within the limits of working space [3].

The basis of the multi-axis machine volumetric accuracy modelling method is formed by the following approaches and assumptions:

1. Multi-axis machine working space is formed with the help of linear axis motion lengths with overlapping of sectors from rotary kinematic pairs rotation movements. Rotary kinematic pairs which do not change coordinate position of the instrument and work piece coordinate system are not considered in configurations.

2. Multi-axis machine tool system may be decomposed into simple elements - units with kinematic pairs ("joints") with its own constructive volume. Each kinematic pair consists of two joint elements - movable and immovable, construction of which depends on certain project synthesis principles, which are numerically formalized by the system of restrictions.

\footnotetext{
* Corresponding author: lukina_sv@mail.ru
} 
3. Machine-tool unit models are the basis for the formation of volumetric accuracy in the working space. It is supposed that each machine tool unit has position deviations due to perturbance, and they are transferred to working space for further integration considering machine n-degrees of movement, distributed on kinematic branches of the instrument (IB) and work piece (WB). As per the typical scheme for unit fixation by means of guide surfaces, machine-tool movable units are considered as fixed-end beams on condition that the area from load point to fixing point (joint) is non-deformable [4].

4. Within the limits of the working space all the functional properties of the machine tools are represented, and are expressed by means of its working characteristic: geometric and kinematic accuracy, hardness, heat and vibration resistance, fast action etc, which are subject to calculation and analytical or experimental identification during the assessment of the technical level of the machine being produced.

5. Volumetric accuracy of the multi-axis machine is formed by the integration of the set of characteristics of the resulting error, on the whole set of points in the working space. Level of working space scanning detalization by means of multitude of points may be determined antecedently in correspondence with the aims and tasks of the certain research. Average machine performance parameters are formed on the basis of the value data in the central point of the working space.

\section{Implementation assessment method for multi-axis machines and its graphic interpretation}

Geometric image of the synthesized machine constructive arrangement consists of the combination of movable unit separate constructions, which are located in the global coordinates respective to working space, according to the earlier chosen scheme of movable unit degree distribution on machine branches.

In accordance with [13] it is necessary to carry out a synthesis of machine constructive arrangements. Each arrangement corresponds to the certain code which characterizes the distribution of the kinematic mobilities on machine branches (IB and WB) relative to stationary (O).

Each movable unit (rotary or translation) is characterized by the set of constructive parameters expressing its ability to ensure necessary coordinate movability and resilience to loads and perturbances. (fig. 1).

The last one is shown through the size of guidelines and contact characteristics of joint elements. Besides, the units has all the necessary movement parameters, this setting the required form and machine working space size. Joint failures or distortion which may occur in the joints of the movable units are the result of the whole set of perturbances (forced, heat, technological manufacturing and assembly defects or others).

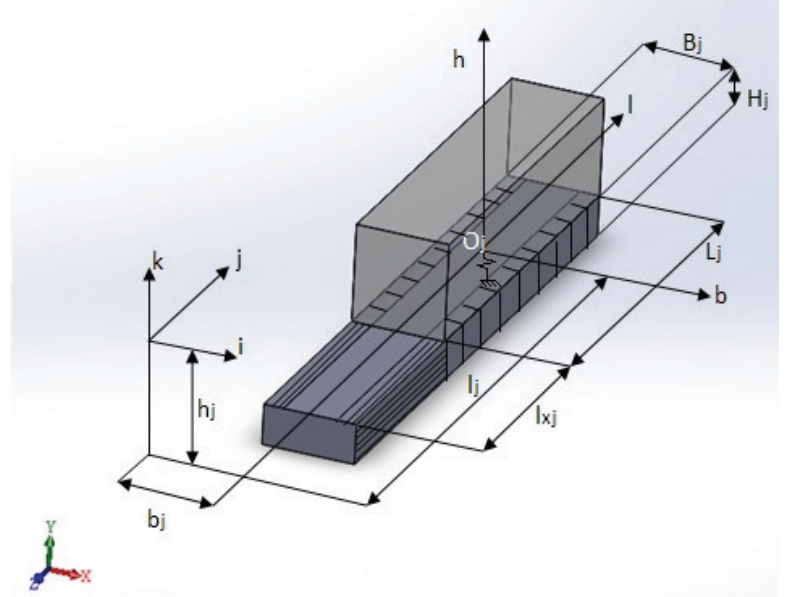

Fig. 1. Machine unit model with translation movement, implementing the joint "kinematic couple P"

Failures in the joints influence the location of machine end units (instrument and workpiece) from the nominal state during formation. In order to assess the degree of influence of each unit failures on to the accuracy of treatment, they should be integrated or differentiated along the working space, estimating the instability. This may be carried out by the procedure of separate joints discrepancy transference into the treatment points in the working space.

While setting initial and boundary conditions of the machine unit calculation scheme the following conditions and allowances are taken into account:

- unit form persistence condition as for absolutely solid body, which is considered during the calculation of joints contact flexibility considering unit form persistence, located from the joint to formation point;

- elasticity condition, as per which machine movable unit fixed on the guidelines has certain elasticity as per Hooke's law [9] and joint's non-disclosure during tipping moment from the cutting forces and the weight of movable unit;

- stability condition, according to which joint area inertia moments are opposed to tipping and twisting moments from the loads which move, push and perturb due to the cutting force and weight;

- cutting force is applied in the working space calculation point (action point), and weight is applied in the centre of unit mass;

- during the joint displacement, there within the working space may occur deviations from the location of the joints carrying instrument and work piece, which influence geometric, static and dynamic machine accuracy.

For the volumetric accuracy analytical assessment of the multi-axis machine Euler laws were used, which allow to form multiple resultant displacements within the working space, caused by cutting force and the weight of movable units. So, for example, the developed model of elastic displacement within the working space along the coordinate axis $i, j, k(x-y-z)$ for the unit moving along the axis $i$ of the machine in the coordinate system is as follows: 


$$
\delta_{i i}=\frac{P_{i} \cdot r_{i j}^{2}-P_{j} \cdot l_{i} \cdot r_{i j}}{L_{i}^{3} \cdot R_{i k}}+\frac{P_{i} \cdot r_{i k}^{2}-P_{k} \cdot l_{i} \cdot r_{i k}}{L_{i}^{3} \cdot R_{i j}} \rightarrow \min
$$

where $\delta_{i i}, \delta_{i j}, \delta_{i k}$ - displacement of the calculated point $\mathrm{p}$ along the axis $i$, caused by rotation of the units moving along the axis $i, j, k ; P_{i}, P_{j}, P_{k}$ - cutting force components which influence the instrument and are directed along the axis $i, j, k ; L_{i}, B_{k}, R_{i j}$, $R_{i k}, R_{j k}$ и $R_{k j}$ - sizes of guiding units moving along the axis $i, j$, $k$, and parallel to axis $j$ и $k ; l_{i}$ и $r_{j}$, - escape (along the length, width and height of the unit) from the treatment point $\mathrm{p}$ to the unit elastic centre measured along the axis $i, j$, and $k$;

Displacement along the coordinate axis $i(\delta i j)$ and $j$ ( $\delta i k)$ for the units moving relative to coordinate axis $j$ and $k$, are determined in the same way.

During the modelling there was used superposition principle, according to which resultant displacement in the working point of the working space is determined by means of transferring all the discrepancies from the whole set into this point. $[9,12]$. Displacement, characterising machine arrangement accuracy as a whole, was determined by the following expression:

$$
\delta_{\Sigma}=\sqrt{\delta_{\Sigma x}^{2}+\delta_{\sum y}^{2}+\delta_{\sum z}^{2}}
$$

where $\delta_{\sum_{x}}=\delta_{x}(I B)-\delta_{x}(W B), \delta_{\sum y}=\delta_{y}(I B)-\delta_{y}(W B)$, $\delta_{\sum z}=\delta_{z}(I B)-\delta_{z}(W B)$.

Here $\delta_{x}(I B), \delta_{y}(I B), \delta_{z}(I B)$ - displacements of the calculated point of the instrument branch along the axis $x, y, z, \delta_{x}(W B), \delta_{y}(W B), \delta_{z}(W B)$. - displacements of the calculated point of the workpiece branch along the axis $x, y, z$.

Calculated scanning of the working space discrete points allows to determine average displacement along the working zone, as well as their spreading.

For the correct comparison of the arrangement variants there must be assured certain conditions of comparability due to the statement of equal guideline sizes in the correspondent units, as well as equal passage length along the axis on all the arrangements. Also there was considered constructive condition of joint associativity which ensures stability of machine operation as a whole $[11,12,15]$.

Developed method of the volumetric accuracy comparative assessment of the multi-axis machines includes the following stages:

1) Creation of the initial geometric 3D-image of the machine;

2) Geometric synthesis of alternative variants of arrangement;

3) Volumetric accuracy calculation for the variants of arrangement.

4) Comparative analysis of the results, and choosing the most appropriate machine arrangement as per the volumetric accuracy.

On the pictures (2) and (3) there is an example of visualization of 3D-geometric synthesis of the arrangement (fig. 2) and volumetric accuracy assessment (fig. 3).

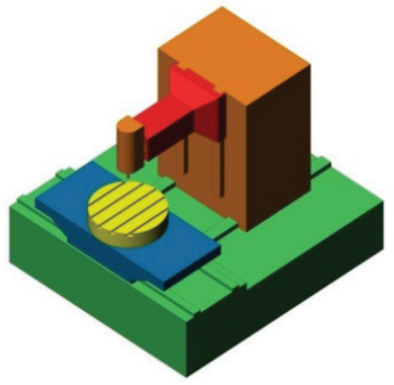

Fig.2. Arrangement 1 (RyTzTy0TxRz)

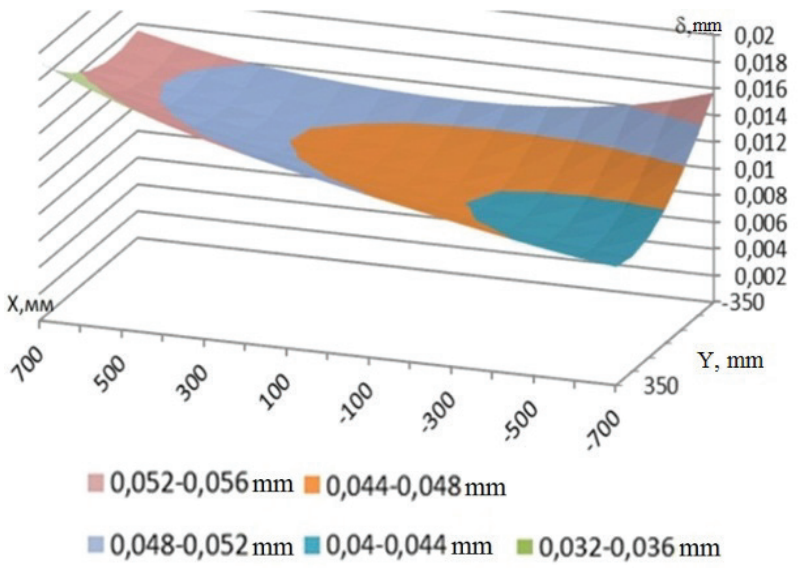

Fig. 3. Machine volumetric accuracy formation (arrangement 1)

Developed method was implemented in Visual Basic.NET and MS Excel. The priority of solving this applied research task was registered by Certificate of computer program registration № 2013661646 [5].

The results of comparative assessment allow to forecast achievable accuracy of multi-axis treatment and choose the best project decision for the machine as per the criterion of volumetric accuracy.

\section{Conclusion}

Formalized results allow to set the connections between construction layout factors and volumetric accuracy output parameters of the multi-axis machine. This may allow to control machine volumetric accuracy on the early project stages while choosing the composition and parametrization.

Visualization of the calculation method is represented by the synthesis of parametric 3D-geometric image of machine arrangement, and formation of the volumetric accuracy graphics in the working space discretized by the multitude of design points.

The analysis of received results allows to justify the best constructive decisions in correspondence with stated technological requirements and restrictions, and also to make recommendations on different use of machine arrangement for various manufacturing conditions.

A further development of the study is the adaptation of the proposed new methodology for technologically conditioned synthesis of multi-axis machines in high-tech engineering industries for the manufacture of 
constructively complex parts of the aviation and defense industries.

\section{References}

1. S.V. Lukina, I.V. Manaenkov, Tehnologicheskij sintez mehatronnyh stanochnyh sistem dlja mnogokoordinatnoj obrabotki// In the collection: XXVI Mezhdunarodnaja Innovacionnoorientirovannaja konferencija molodyh uchjonyh i studentov MIKMUS-2014. Works of a conference. Russian Academy of Sciences; RFFI; Office of power, mechanical engineering, mechanics and management processes; Institute of engineering science of A. A. Blagonravov of RAS. p. 428-431. (2015)

2. S.V. Lukina, S.N. Ivannikov, I.V. Manaenkov, Povyshenie jeffektivnosti mnogokoordinatnoj obrabotki putem optimizacii komponovki mnogoosevoj stanochnoj sistemy. News of the MAMI Moscow state technical university, № 2 (20), p. 3437. (2014)

3. Ju.D. Vragov, Analiz komponovok metallorezhushhih stankov/ Osnovy komponetiki (M.: Mashinostroenie, 1978)

4. D. N. Reshetov, V. N. Portman, Tochnost' metallorezhushhih stankov (M.: Mashinostroenie, 1986)

5. S.V. Lukina, I.V. Manaenkov, Certificate on the state registration of the computer program of Rospatent № 2013661646 «Sistema avtomatizirovannogo sinteza sredstv osnashhenija mnogoosevoj obrabotki» (2013)

6. S.V. Lukina, Prognosticheskoe modelirovanie proektnyh innovacionnyh reshenij po konfiguracii sredstv osnashhenija vysokotehnologichnyh proizvodstv, Innovacii. № 8 (202), p. 68-71 (2015)

7. V.M. Makarov, S.V. Lukina, Naukoemkij inzhiniring $v$ zadachah tehperevooruzhenija. RITM: Remont. Innovacii. Tehnologii. Modernizacija № 8 (8), p. 16-20 (2013).

8. S.V. Lukina, Metodika optimizacii proizvodstvennoj dejatel'nosti promyshlennogo predprijatija na osnove kompleksa prognosticheskih modelej formirovanija $i$ vybora proektnyh innovacionnyh reshenij $v$ oblasti vysokotehnologichnyh proizvodstv. Vestnik MSTU Stankin, № 1 (32), p. 125-129 (2015)

9. S.V. Lukina, S.N. Ivannikov, M.V.Krutjakova, I.V. Manaenkov, Tehnologicheskij sintez mehatronnyh stanochny sistem dlja mnogoosevoj obrabotki, Izvestija Moskovskogo gosudarstvennogo tehnicheskogo universiteta MAMI, T. 2. № 1 (15), p. 46-51 (2013)

10. S.V. Lukina, Razrabotka kompleksa prognosticheskih modelej formirovanija $i$ vybora proektnyh innovacionnyh reshenij $v$ oblasti vysokotehnologichnyh proizvodstv, Aktual'nye problemy v mashinostroenii № 2, p. 451-456 (2015)
11. S.V. Lukina, S.N. Ivannikov, I.V. Manaenkov, Metodika formirovanija $i$ vybora optimal'noj konfiguracii formoobrazujushhej sistemy mnogokoordinatnoj obrabotki, News of the MAMI Moscow state technical university T. 2, № 2, p. 237242 (2013)

12. V.M. Makarov, S.V. Lukina, Upravlenie konfiguraciej izdelij dvojnogo naznachenija. Glavnyj mehanik № 3, p. 28-34 (2015)

13. V.M. Makarov, S.V Lukina, Programmy razvitija jekspertnyj podhod. RITM: Remont. Innovacii. Tehnologii. Modernizacija № 9 (97), p. 19-23 (2014)

14. V.M. Makarov, S.V. Lukina, P.A. Lebed' Imitacionnoe modelirovanie $v$ zadachah tehnologicheskogo inzhiniringa. RITM: Remont. Innovacii. Tehnologii. Modernizacija № 2 (70), p. 16-22 (2012)

15. S.V. Lukina, Avtomatizacija procedur formirovanija $i$ vybora strukturnyh komponovok sbornyh rezhushhih instrumentov na jetape tehnicheskoj podgotovki proizvodstva, Vestnik Saratovskogo gosudarstvennogo tehnicheskogo universiteta, T. 3, № 1 (57), p. 241-247 (2011) 